\title{
Colin Scrimgeour
}

\section{and New Zealand broadcasting}

\section{PATRICK DAY}

Colin Graham Scrimgeour was born into a poor family of six children at Wairoa in 1903. He left school at the age of eleven and began work at the Gisborne freezing works. Both his parents, his father first, died from cancer after considerable suffering. At the age of twenty, after his mother's death, he resolved to become a minister. His was one of the more unusual callings for he had little church experience, he said he had never been in one, and had no preference for any particular denomination. Reasoning that neither the Catholics nor Anglicans would accept him he approached the Methodists. After four unhappy months in their Theological College he left by mutual agreement and became a home missionary, the junior grade of the Methodist ministry. For three years, as he termed it, he "preached the Jesus-type of socialism' and at the end of 1926 was appointed to establish the Methodist Central Mission in Auckland. He began this just as the numbers and the distress of the poor of Auckland began to swell with the onset of the depression. His religious beliefs were soon distinguished by his emphasis on practical, worldly assistance. JohnA. Lee recalled being introduced to Scrimgeour by Pat Hickey who described him as 'a parson for whom I have considerable respect, a fellow who is more concerned about feeding the people than about praying for them'.

By the 1930s Scrimgeour was a well known figure in Auckland. His exposures of the nature and extent of poverty there had been well publicised in the press, particularly by the Sun. Also, in a controversial but successful attempt to take his church to a new congregation, Scrimgeour had begun holding his Sunday services in the Strand Theatre and had included films, along with singing and sermons, as part of the

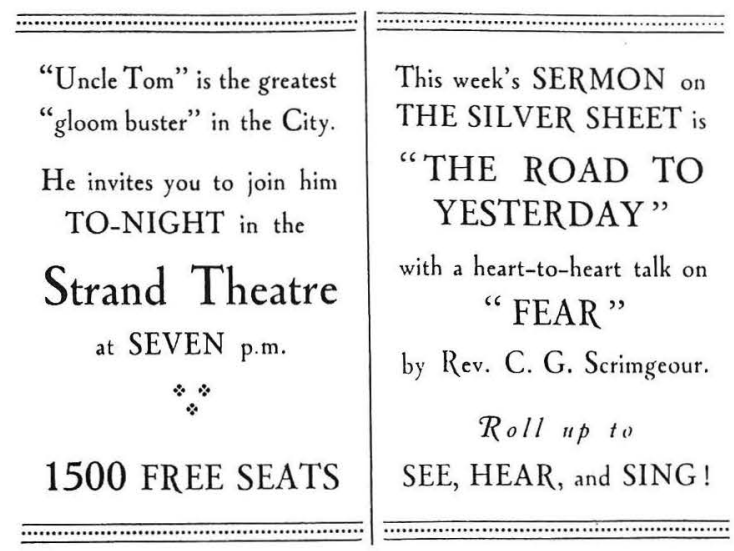

service. The 1500 seat theatre regularly had a capacity congregation.

Scrimgeour's colleague in the Strand Theatre services was the Reverend Tom Garland, who led the singing, and it was through him that Scrimgeour was introduced to broadcasting where he found his largest audience and his own metier. Broadcasting was at the time divided into the YA stations, funded by the listeners' licence fees, and the $B$ stations, private stations generally backed by music and radio firms. Garland, who became best known for his years of work with Auckland choirs, was associated with 1YA's religious and children's programmes and had been advocating the introduction of non-denominational religious programes of an informal nature for both children and adults. Garland's attitude was summed up in his radio motto: 'You go to your church. I'll go to mine, but let us walk together'. In December 1930 the firm of Lewis Eady began $1 \mathrm{ZR}$ and Garland accepted the offer of a free hand to introduce his ideas. He took control of the $1 \mathrm{ZR}$ religious and childrens's programmes.

Scrimgeour began taking one of the morning devotion sessions on 1ZR and, partly because he lived close to the station, took over more and more of them. Through his children's session work he became known as Uncle Scrim. He was not keen on the title. Nor did he like being called Reverend. Over 1931 and 1932 he gained a radio experience Above: A posteradvertising Garland and Scrimgeour's Strand Theatre services. 
and developed a broadcasting style that was to make him the most influential of all who had access to the microphone. Two references he received in 1932 attest to the high regard in which he was held and to his social and political sympathies. The first is from the 1ZR Station Director and introduces Scrimgeour to his $2 Z W$ Wellington counterpart. 'Our Uncle Scrim (Rev C G Scrimgeour) is an outstanding personality of Auckland broadcasting, conducting the 1ZR Devotional Services, and doing more good to the square inch than all the politicians put into one bag, to say nothing of Radio Boards and the like ... Open the door wide - give him the freedom of the city and of $2 Z W$, and the keys of the treasury or family vault - anything is safe with him'. The other is from a labour leader sought by authorities for his part in the 1932 Queen Street riots. 'Dear Comrades, The Rev Scrimgeour is a personal friend of mine. Whilst I was under cover he was trusted and helped me in every way. Please trust him with any literature he requires and give heed to any suggestion he may bring forward. Yours in revolt, Jim Edwards'.

While New Zealand allowed private ownership of radio stations, these were not permitted to advertise nor otherwise sell broadcasting time. Thus the B stations could exist but could not earn a living. Most stations were funded by their owners with donations also coming from listeners, many of whom paid a subscription to belong to their local radio station club. Towards the end of 1932

Scrimgeour became involved in the politics of the B stations when he organised a petition, supported in the House by Labour members, especially their leader, Michael Joseph Savage, which sought the introduction of programme
sponsoring so as toallow B stations to earnanincome.

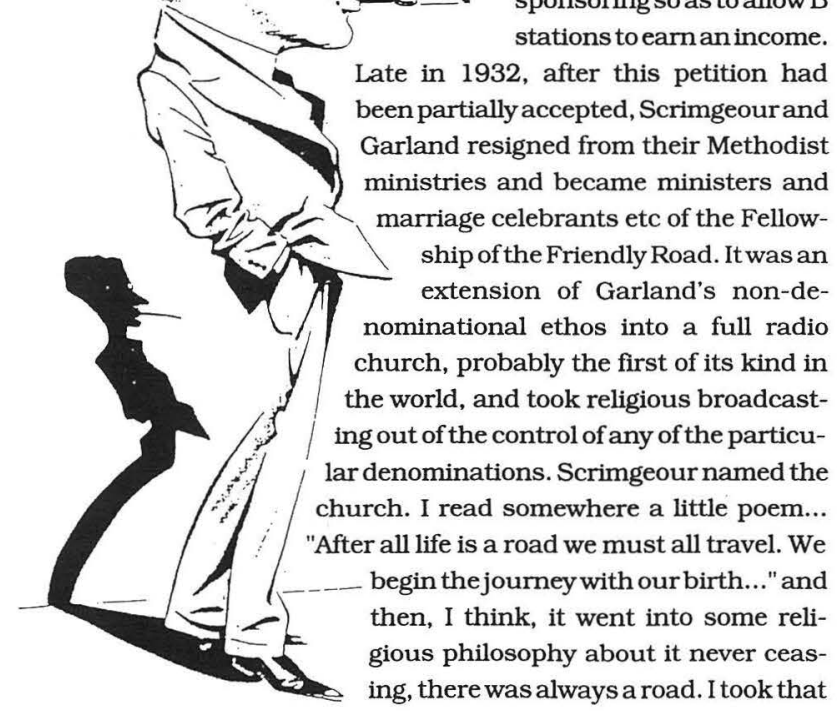

title as a road that we must all travel. Full stop. Let's make it a Friendly Road'. To modern ears the church was mild in tone and saccharine in philosophy. Such criticism was also present in the 1930s. But more dominant was the comfort and encouragement given to the many who were facing great hardship.

Scrimgeour's main programme was a Sunday evening session titled 'Man in the Street', in which he discussed matters of religious and social concern. The session was presented with a carefully chosen style. 'I never raised my voice. I spoke quietly. If I wanted emphasis I made the emphasis not in loudness as a tub-thumping preacher or a politician would do. I made the emphasis in the same quiet tone and I always added the question, "You tell me". Although heard principally in Auckland, the Man in the Street session during 1933 became the voice of the common man and woman and Scrimgeour became the country's major broadcasting voice.

In June 1933 the Lewis Eady firm was ordered to close down $1 Z R$ for persistent breaches of the radio regulations limiting advertising. Permission to restart transmissions came a week later on the eve of a protest meeting in the Town Hall which the New Zealand Herald reported as attended by 1500 people. The meeting was a demonstration of the public support for 1ZR and the B stations generally and was the first time Garland and Scrimgeour used their considerable experience of attracting large crowds in direct opposition to a Government action.

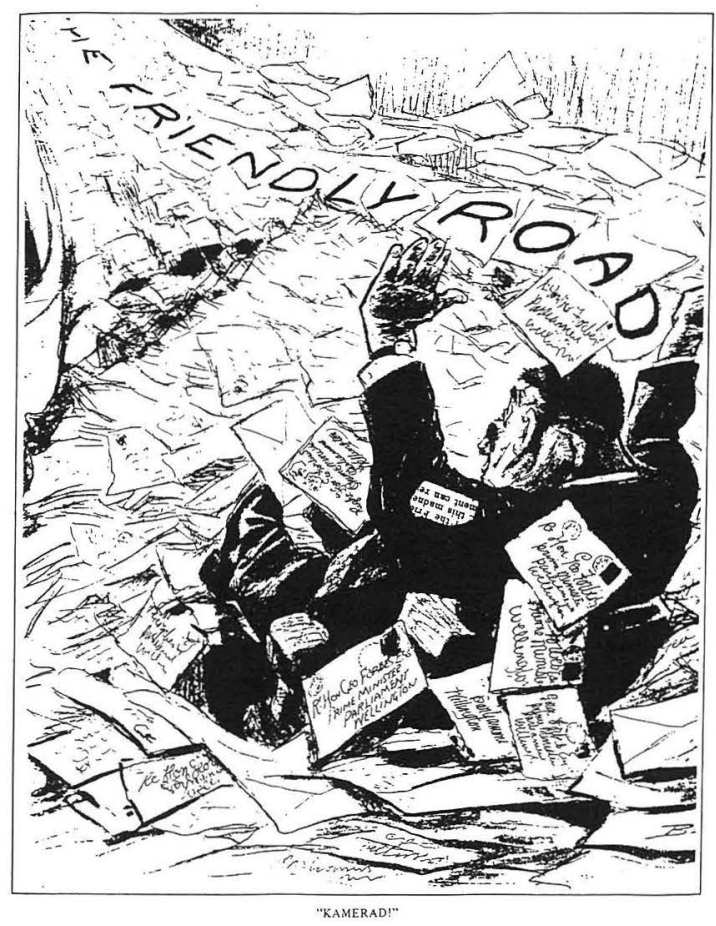


Government policy was oriented towards closing down the $\mathrm{B}$ stations and having all New Zealand broadcasting under the control of the Broadcasting Board. To this end, late in 1933 it was announced that permission for sponsoring of programmes would be withdrawn. Having deprived the stations of the right to earn an income, the Government negotiated with Lewis Eady's in Auckland and Hamilton Nimmo's in Wellington, the 2ZW owners, and purchased and closed down both $1 Z \mathrm{R}$ and $2 Z \mathrm{~W}$, the two main B stations. Garland and Scrimgeour were thus left without a station. No more licences were to be issued and they made strenuous efforts to purchase an existing licence. They were successful with the owner of the $1 \mathrm{ZB}$ licence. Garland has been recorded as arranging the purchase for $£ 50$, sealing it with a deposit of £5. Scrimgeour has also claimed he bought $1 \mathrm{ZB}$ for a price of $£ 100$ which he raised by selling his wife's piano. Whichever version is correct it was the lesser part of returning the Friendly Road to the air.

The more difficult task was persuading the Government to allow the transference of the licence. The Broadcasting Board advised against it and considered it its duty to stress the extreme danger of establishing a precedent inimical to broadcasting and full of potential trouble to established authority'. It argued, 'Once a sufficient following is obtained, it becomes a difficult, if not an impossible task, to exercise reasonable control over the individual. We feel strongly that it is impossible to gauge the reaction on both the Government and the Board should the gentleman in question (Scrimgeour) be given the desired facilities'. Garland and Scrimgeour publicly and pointedly demonstrated that the Friendly Road already had 'a sufficient following' which was not to be denied. In support of the Friendly Road, 'an estimated gathering of over 14,000 people met in Carlaw Park. The combined brass bands of Auckland turned out in full force. The day was fine. Uncle Tom led the band and the people in community hymn singing. Uncle Scrim addressed the multitude'. That evening a service was held in a packed Town Hall and, via a public address system, the congregation included an estimated crowd of 6000 outside. A massive letter writing campaign was organised and the Government crumbled under the pressure. The licence was granted and the 1ZB Friendly Road station was officially opened by Gordon Coates, the Deputy Prime Minister.

In 1934 and $193512 B$ was the major B station and one of the few to grow beyond the confines imposed by a parttime voluntary staff. It existed precariously on the financial generosity of its listeners and employed a small staff. The announcing staff included Scrimgeour, Garland, Rod Talbot famous for his Digger's sessions, Dudley Wrathall, a long-

Opposite: Prime Minister Forbes surrenders to the Friendly Road letter writing campaign. New Zealand Observer, 7 December 1933

Above: Minhinnick's 1930's 'Friendly Road ' cartoons.

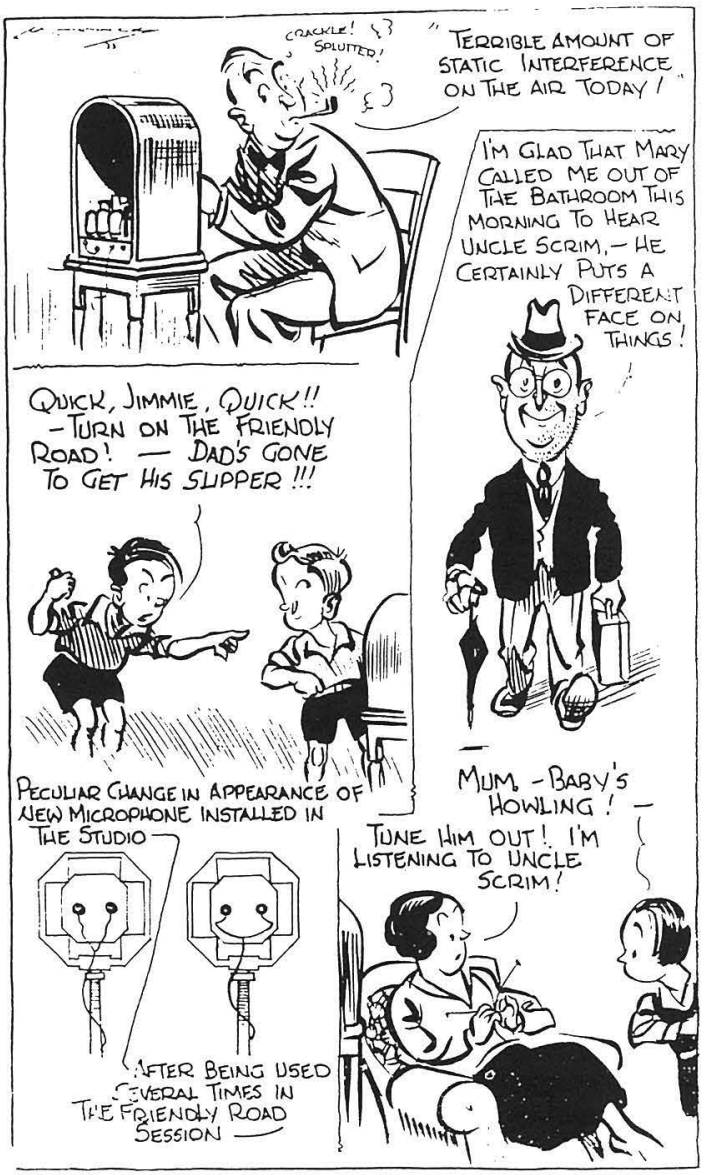

time Auckland radio personality and not least Daisy Basham, the principal developer of New Zealand women's sessions. Daisy's own distinctive announcing style, epitomised by her cheerful opening, 'Good morning everybody, good morning, good morning' was in deliberate distinction to the anonymity then forced by the Board on the YA announcers. One of her great strengths for $1 Z \mathrm{~B}$ was her ability to evade the advertising ban; 'I've just had a lovely cup of tea. I can't tell you what sort it was but it was a dust-free one'. As well as a radio station the Friendly Road functioned as a church with funerals, marriages and baptisms and services being performed. Many marriages and most baptisms were broadcast. It was also a social service centre collecting and dispersing food, clothing and money.

Scrimgeour's broadcasting importance at 1ZB lies in his often outspoken talks. Controversy had been banned from radio since the first radio regulations. The one loophole had been the acceptance of religious broadcasts and Scrimgeour was well aware it was his status as a minister that allowed the Friendly Road to exist and him to broadcast. He was also 
aware that continuing public support was needed and during 1934 and 1935 much attention was paid to this. He spoke in many North Island centres. The public support for the Friendly Road was again demonstrated at the station's second anniversary. Six brass bands entertained the crowds at a Carlaw Park rally and two services were held in the Town Hall, which was packed on both occasions. Special trains were required to bring the country supporters to Auckland.

In these years Scrimgeour also made regular visits to Sydney where he broadcast from 2UE, a private station owned by the Sydney Sun. He was able to keep his Man in the Street session going in Auckland by use of the newly available acetate disc recording technology. His Sydney show was successful and he was assured of future employment there should he need it. He was less successful with the Australian Broadcasting Commission. He applied there for work but they checked with the New Zealand Broadcasting Board who replied that they considered Scrimgeour as dangerous and would never employ him.

In New Zealand Scrimgeour founded and became President of the Federation of B Station Proprietors. There was official concern that 12B's example was spreading and threatening the Government's broadcasting policy. In Dunedin the Rev Leslie Neale started New Zealand's second radio church, the Church of the Helping Hand, which operated through $4 \mathrm{ZM}$. Moreover the conventional churches were unhappy with the publicity and following the radio churches were receiving and wished to emulate them. There was a growing fear among officials in 1934 and 1935 that the shrinking again expand with a growth of church-based B stations.

In 1935 Scrimgeour gave concern to broadcasting officials not just by his agitation for the $\mathrm{B}$ stations but by his growing disregard for the radio regulations. Scrimgeour's life story had been published. In one incident Scrimgeour 'stated that owing to the restricted liberty with regard to giving publicity to the book over the air it has not been selling; but he felt that as money was so urgently needed, he was justified in making a breach of the regulations on this occasion, and putting out a further appeal on behalf of the booklet'. Scrimgeour's disregard for the broadcasting restrictions increased as the election grew closer and took on more of a political tone. For the Broadcasting Board the major incident was one where, in spite of Parliamentary candidates not being allowed to broadcast, 1ZB allowed John A. Lee to broadcast. His topic was Poetry in the Trenches but it was the fact of broadcasting rather than the topic that was the point. It was seen as a 'direct flaunting of the (Broadcasting) Board's instructions' leaving 'no alternative but to accept the challenge and take the matter up'. But it was also considered that $1 \mathrm{ZB}$ was 'endeavouring to provoke the Board to action so that they may create and stimulate sympathy'. No action was taken and this was most unusual. All other stations were strictly controlled. In another incident in the same week as Lee's broadcast, an officer at 3YA, a Board station, was dismissed for allowing the Mayor of Christchurch, a Parliamentary candidate, to broadcast. 1ZB's freedom from official reprisal indicated a real fear that action against the station would again provoke large scale demonstrations against the Government. It was noted by Scrimgeour's colleagues: 'Scrim has been giving the Government Hell in Auckland but they have not raised one protest'.

In the election year of 1935 Scrimgeour became a more obvious advocate for the Labour Party. In particular, thousands of copies of two pamphlets, The Scandal of New Zealand Broadcasting and More Scandalwere printed. These included calls to support Labour. This was proper political activity in that the calls were printed rather than broadcast. But there was little doubt among the public and none in the Broadcasting Board and the P\&T Department that Colin Scrimgeour and 1ZB were Labour supporters. The official apprehension was that Scrimgeour, in the last days of the campaign, would broadcast appeals for the electorate to vote Labour.

The week before the election a Wellington P\&T Department radio engineer was told by his superiors that, in the following Sunday's Man in the Street session, Scrimgeour would be advising his listeners how to cast their votes. The engineer was instructed to travel to Auckland, prepare for and blot out Scrimgeour's broadcasts when he began so to offend. Technically it was not a difficult task. The engineer did as instructed and later maintained he jammed the broadcasts only when Scrimgeour did begin so to offend.

The jamming apparatus was discovered the next morning and, now back in Wellington, the engineer was summoned to the office of George McNamara, the P\&T Department Director-General. McNamara said, 'I've made a blunder', and asked the engineer to become a scapegoat and admit to mistakenly and carelessly interfering with the $1 \mathrm{ZB}$ signal during experimental work. He refused but offered, as a loyal officer of the Department, to keep silent. McNamara issued a statement that the jamming was accidental. Few

Opposite: Savage and Scrimgeour at 1ZB as Labour 1935 election victory is announced. Tom Garland is in the background, centre right. 
believed him. The jamming became a cause célèbre and,as Lee noted, "kept pressure on the Government right till election day...it... caused people who might not have voted to be so aroused that few votes were lost through indifference'.

The Minister, Adam Hamilton, took the proper constitutional stand and assumed responsibility for his Department's actions. However, he denied giving orders for the jamming. Nor is it likely that Hamilton who, in spite of 1ZB's previous offences, had accepted the political impossibility of closing the station, would have changed his approach in so politically naive a fashion as to jam Scrimgeour's final preelection broadcast. Within the Department it was assumed McNamara was responsible. An anonymous judgement on his part in the affair was given three years later in the P\&T Department employees' magazine, The Katipo, as one of the verses in a squib suggesting the Director-General resign:

Then pand'ring to the powers that be:

'I'll wreck a radio' said he,

And smiled with hopes of extra hoot

Until those powers got the boot.

He wrecked the radio alright

And his patrons overnight.

Labour's promise was that the B stations would live. Savage, now Prime Minister, assured Scrimgeour he would get the licence for Auckland and,as Wellington had no B station, told him to prepare to operate the commercial station there also. Over the next months the Government seemed to be signalling it would allow private stations to advertise but, away from the public gaze, its policy was an issue of Cabinet and Caucus dissension. The Party had long advocated the State ownership of radio. Its promises to the B stations were in opposition to its own broadcasting policy and to its wider socialist philosophy. After the election there was a split, approximately between the Auckland members, led by Savage, and the rest, led by Peter Fraser and Walter Nash. The eventual decision, which the Government maintained was to let the B stations live, started commercial radio as a Government Department. The reason given for the policy change was the fear of Labour's old enemy, the press. It was argued that newspaper proprietors were poised to take over the B stations. It was certainly true that they did show such interest and the Auckland Star directors had been the effective owners of IZM since the middle of 1934 . But such newspaper intent had been evident well before the election and before Labour issued its promise to let the $B$ stations live.

Scrimgeour was the pivot in the public acceptance of the new policy. After the election he was the only public figure with a popularity rivalling that of senior Labour figures. Had he chosen he could have led an expression of public discontent with Labour's broken promise. However he accepted

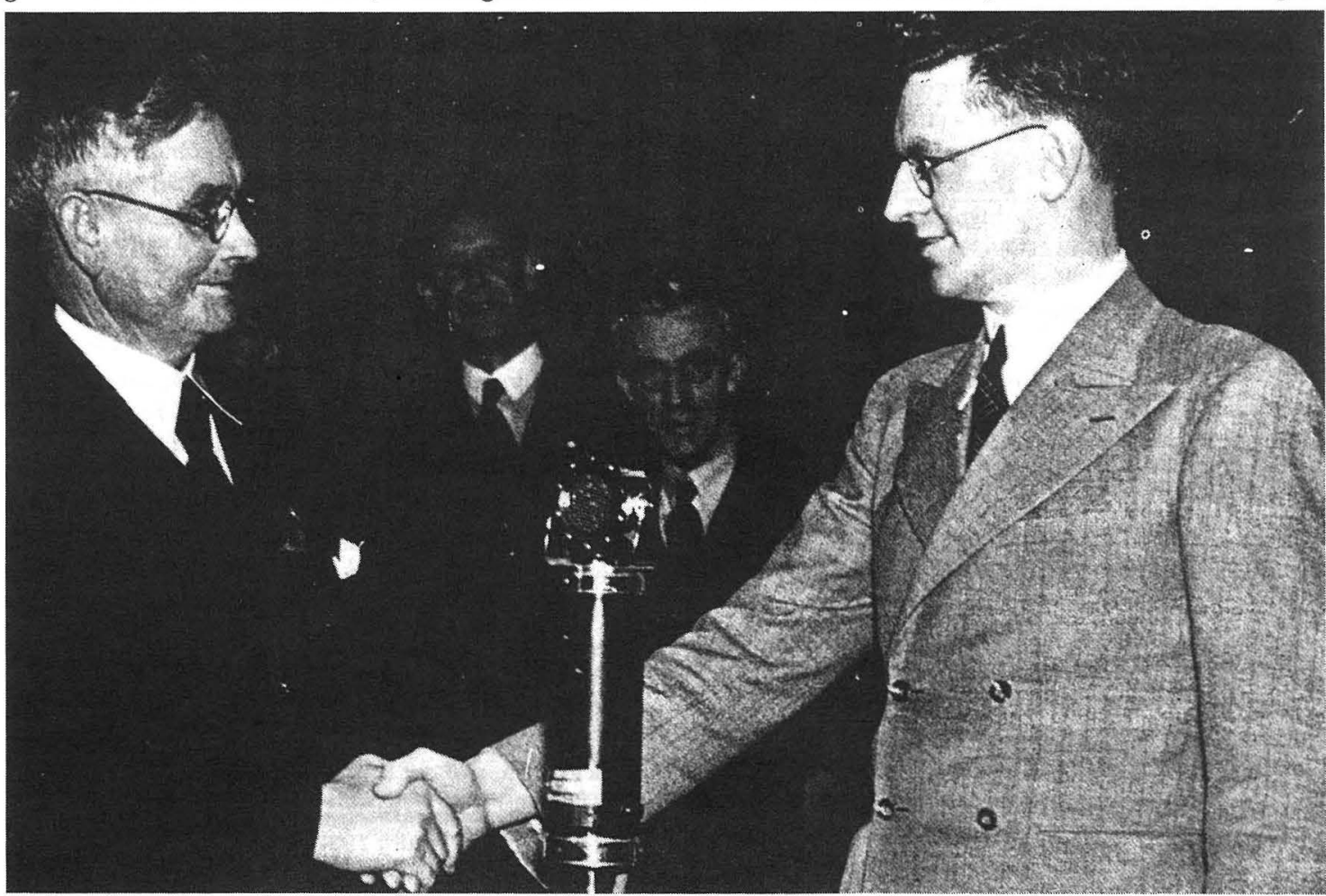


and supported the change. Furthermore, as the B stations' proprietors' principal negotiator with the Government, he kept his colleagues less than fully informed of the nature of the Government's changed policy and thus nullified opposition from the B station proprietors, who were the major losers from the policy change.

Scrimgeour stated he was offered but declined the position of Director of Broadcasting that went to James Shelley. There is no corroborative evidence for this statement and it is unlikely to be true. As well as being split over the B station policy, the Government was also split in its attitude to Scrimgeour, with the southern members always regarding him with deep suspicion. However he could not be ignored. He was an ally of Savage, necessary for the acceptance of Labour's broadcasting policy and a public figure of immense influence. Fiveweeks afterShelley's appointment, Scrimgeour was appointed Controller of Commercial Broadcasting. $\mathrm{He}$ took up the position immediately and thus started some months before Shelley. He was not under Shelley but became the Head of a separate Government Department. The position was not advertised and the appointment was made by Savage personally.

Scrimgeour drove a hard bargain before accepting. Part of the bargain was financial and most subsequent criticism centered on this. He was appointed at a salary of $£ 500$ a year plus a commission of $7.5 \%$ of the gross advertising revenue. After much press criticism thesearrangements were altered and Scrimgeour received a straight salary of $£ 1500$ a year, the same as Shelley. These salaries were not the highest in the Public Service butwere in the upper range of those received by Heads of Departments. Had Scrimgeour remained on his commission he would have received $£ 7380$ and $£ 12097$ in 1937 and 1938 respectively.

What was of greater significance than Scrimgeour's pay, though it received less discussion, was the broadcasting freedom he was given. The 'Man in the Street' session was to continue and Scrimgeour was to run it as he wished. As Savage's successor as Minister in Charge of Broadcasting was to note, 'Mr Savage gave Mr Scrimgeour the right to say whatever he liked and to talk as often as he liked'. It was a right that contrasted starkly with those of other broadcasters both inside and outside New Zealand. Labour maintained a

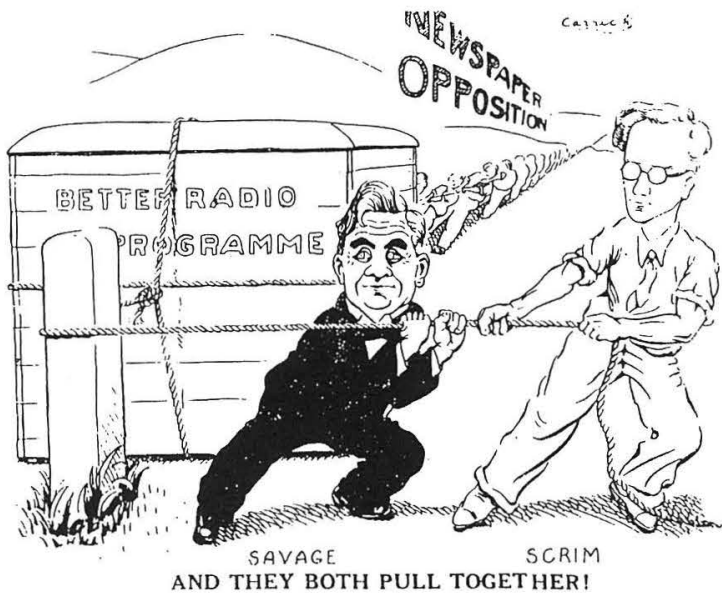

ban on controversial broadcasting and only Scrimgeour was beyond a day-to-day Ministerial censorship. In comparison with the BBC's right to broadcast controversial material but not to editorialise, the New Zealand broadcasting services could do neither, except for Scrimgeour who could do as he saw fit.

From late 1936 to mid 1943 Scrimgeour was in charge of and developed the commercial stations. Although Government run they began as a continuation of the Friendly Road. This was a major factor in the public perception that the $B$ stations were continuing. All the Friendly Road programmes were transfered to the commercial $12 B$ and all its personnel who wanted it were given full-time employment in the new order. YA station personnel regarded the commercial service as a victory for their enemy and relations between the two organisations were at best strained, at worst acrimonious, until the $1950 \mathrm{~s}$. The continuation of the $1 \mathrm{ZB}$ call sign and its extension to 2,3 , and $4 Z B$ was a further sign of the victory of the Friendly Road. The commercial stations enjoyed by far the majority audience. In the absence of any detailed listener research it is impossible to be definite on this point, but most estimates put the commercial stations as receiving $80 \%$ or more of the available listening audience.

Commercially the new stations were run on a hard-sell policy modelled on the Australian private stations. Much of their success can be attributed to Scrimgeour. He employed a capable staff and had an informal administrative style accepting of his employees' initiative, which engendered both loyalty and achievement. He showed himself possessed of leadership and commercial abilities to rival his other gifts.

However his style was less than appreciated by his superiors and his enemies. Commercial broadcasters were quick to enthuse about and try new ideas. Action rather than

Above: Carrick's view of the Savage-Scrimgeour co-operation. Jack Blunt, 23 February 1937.

Opposite: A 1938 election poster view ofS Scrimgeour's influence. 
scrutiny was the approach and Scrimgeour was regularly to seek approval for his innovations and his expenditure after, rather than before, action was taken. He was soon regarded as intractable and unamenable to Public Service discipline. Rumours of financial impropriety dogged him. He was never to be charged, much less found guilty of any offence, but his financial actions and those of his senior executives were regularly queried in the press and in Parliament. Furthermore the commercial stations cultivated a high-expenditure, business image which was seen as unbecoming to the Public Service. The stations and Head Office were described as unnecessarily luxurious. Scrimgeour's own expenditure as Controller, particularly on travel, was also regularly criticised. He was reluctant to use a train or boat when a plane was available. He made trips to Australia and the United States which were seen as unnecessary. His personal first class style was defended as part and parcel of the business image of commercial radio but won him many enemies.

Politically, both Shelley's national and Scrimgeour's commercial stations were used by Labour to take their message to the people. The Opposition regarded radio as a propaganda vehicle for the Government, and Scrimgeour, though not Shelley, as an ardent Labour ally. Radio and Scrimgeour were among the issues in the 1938 election campaign. Probably Scrimgeour's major contribution to the campaign came when he answered accusations from Justin Power, a National Party official, that 'poisonous political propaganda' was being spread on Sunday evenings in the name of religion'. It was an obvious reference to the Man in the Street programme. Scrimgeour's reply to Power the following Sunday evening was a sustained attack on the Opposition and the press and included the declaration 'You and the gang who employ you are unmitigated and malicious liars'. In the Parliamentary debate that followed Savage stopped short of endorsing Scrimgeour, but stated the broadcast was understandable and made it clear he would not be accepting the resignation of Scrimgeour who, Savage said, remained his personal friend.

In spite of his ability Scrimgeour was reliant on the protection given by his personal relationship with the Prime Minister. Savage's death in March 1940 removed that and also came at a time of particular dissension within the Labour Caucus with the expulsion from the Party of Lee. It was in this turbulent atmosphere that Scrimgeour ignored his newly weakened position and immediately set himself irrevocably at odds with Fraser, the new Prime Minister. Broadcasting after Savage's funeral he said, 'The name of the messenger sent to me by Mr Savage to ask me to accept appointment was John A. Lee. May I be pardoned for saying that the greatest tribute we can pay to him whose departure we mourn is that the big-heartedness of New Zealanders may rise above the merciless bludgeonings of misunder-

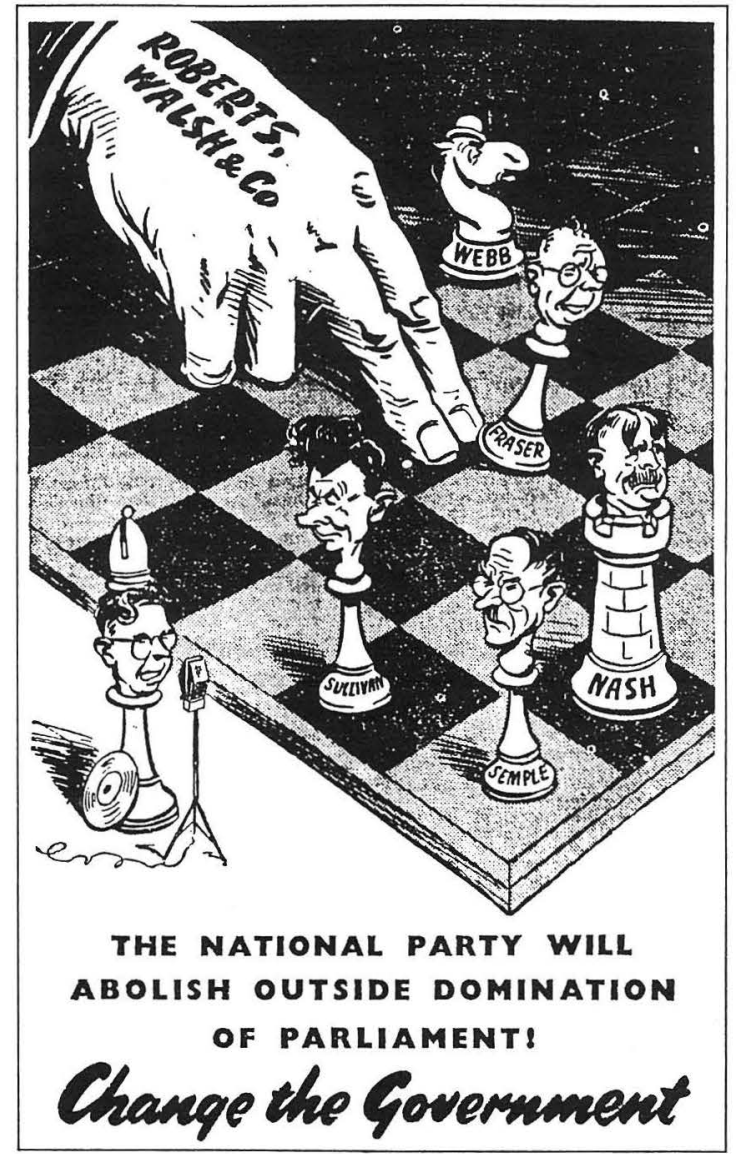

standing, and may not lose for us two men who desired to serve the nation - the one by death, the other by dissension'.

Scrimgeour was not to be pardoned and one of Fraser's first actions as the new Minister in Charge of Broadcasting was to suspend the Man in the Street session. Fraser was not bound by the personal arrangements made by Savage with Scrimgeour and had no obligation to continue Scrimgeour's unique broadcasting rights. However, in spite of being Prime Minister, Fraser was forced to heed the strong public support and trade union backing for Scrimgeour. The Man in the Street session was resumed after being off the air for only one week.

It was in 1941 that the programme was finally taken off the air. In May Scrimgeour announced in his Man in the Street session that the topic of one of his future broadcasts would be 'Sex and its Contagious Diseases'. He then proceeded immediately to discuss the topic by stating what he intended to cover and by quoting liberally from various books on the subject. The broadcast provoked considerable comment, little of it favourable. Scrimgeour left for a visit to 
Australia after this broadcast and, while he was away, the Minister moved to restrict Scrimgeour's right to run the Man in the Street programme as he pleased. The Minister by now was David Wilson but it was generally considered that Fraser kept a close personal watch on broadcasting throughout his Prime Ministership. On his return Scrimgeour asked for but was denied permission to broadcast an Auckland meeting of the Society for Closer Relations with Russia. His response in an August Man in the Street session was to discuss the meeting and to introduce and play a recording of the speech given at it by the Rev Percy Paris. Wilson regarded this as 'deliberately evading the instructions given' and suspended the session. But the rationale for the suspension became confused with conflicting statements that it both followed from the pro-Russia broadcast and was caused by Scrimgeour's ill-health. In September 1941 Scrimgeour went on sick leave for what was later reported as a mild nervous breakdown.

While the Man in the Street session was never resumed Scrimgeour was not otherwise prohibited from broadcasting. However he remained contentious and increasingly came into conflict with his Minister and with J.T. Paul, the chief wartime censor. In February and March 1942 Scrimgeour was upbraided by Wilson for broadcasting talks first on the Red Army and then on the availability of labour to build air-raid shelters, without previously submitting the scripts for censorship. After the second incident Wilson noted on the file copy of his letter to Scrimgeour, 'How many times do we have to threaten him with dismissal before we do it?'

During this time the Government was attempting to amalgamate the two broadcasting services so as to release radio technicians for the war effort. The need for technicians was real but it was also an excellent pretext for the Government to rid itself of Scrimgeour. Wilson suggested to Scrimgeour the Services be amalgamated and Scrimgeour work under Shelley. After interviewing him Wilson reported Scrimgeour as being 'emphatic in saying he would not work under Shelley... In a threatening manner he said that if he was not appointed (Director) he would "go to work on the wharf" also that if we wanted a fight we could have it... When he left the understanding was "Director or nothing"' . Scrimgeour went public with the entire dispute and did apply for and was granted membership of the Waterside Workers' Union. The engineering sections of the two services were combined but otherwise, in a victory for Scrimgeour, the amalgamation plans, in spite of being approved by the Cabinet, were not proceeded with.

There continued to be complaints from J.T. Paul about Scrimgeour's disregard of the censorship requirements and, in June 1942, the Minister ordered that all of Scrimgeour's scripts were to be submitted to the Minister personally. Thus Scrimgeour was not to broadcast without Ministerial approval for each broadcast. In February 1943 in a deliberate attempt to test the Minister, Scrimgeour had an innocuous script submitted and passed by the censor. Scrimgeour then personally announced this trivial programme and the following day was dismissed by Fraser and Wilson from his position as Controller. The dismissal caused much concern in Labour Party and trade union circles and the executives of the Party and the Federation of Labour set up a joint committee to attempt to effect a reconciliation. As a result Scrimgeour was reinstated after signing a document that formally ended his unique broadcasting rights. Publicly, the reinstatement was regarded as anothervictory forScrimgeour and an instance of Party and trade union 'bosses' being the real rulers in New Zealand.

Meanwhile Scrimgeour was coming under the eyes of the military authorities as men of his age were balloted for service. As Head of a Government Department he could reasonably have expected to be excused military service, but Wilson made it clear he would not be appealing on Scrimgeour's behalf. However the Friendly Road Church did appeal. Subpoened to appear before the Appeal Board, Wilson effectively scuttled Scrimgeour's appeal by telling the Board that Scrimgeour's absence would not adversely affect broadcasting. He stated, 'I might get more willing and loyal service from his successor'.

John A. Lee, by now Scrimgeour's only real ally in Parliament, queried 'whether certain persons will use the balloting organisations not for the purpose of recruiting people for the Army but in order to revenge themselves against certain people... I felt that the Board was used as an instrument of Ministerial vengeance'. Scrimgeour entered the Air Force in June 1943 but, before doing so, made press statements that he was being railroaded into the Services and that his case was one of discrimination and victimisation by the Prime Minister. He also offered a new version of the document he had signed at his reinstatement, including that assertion that it had been agreed that any military service on his part would be restricted to one month's training in each year. Such statements were a clear breach of his signed agreement and also signalled his loss of support at the higher levels of the Labour Party and the Federation of Labour. The members of the Labour Party and Federation of Labour committee promptly denied the accuracy of 


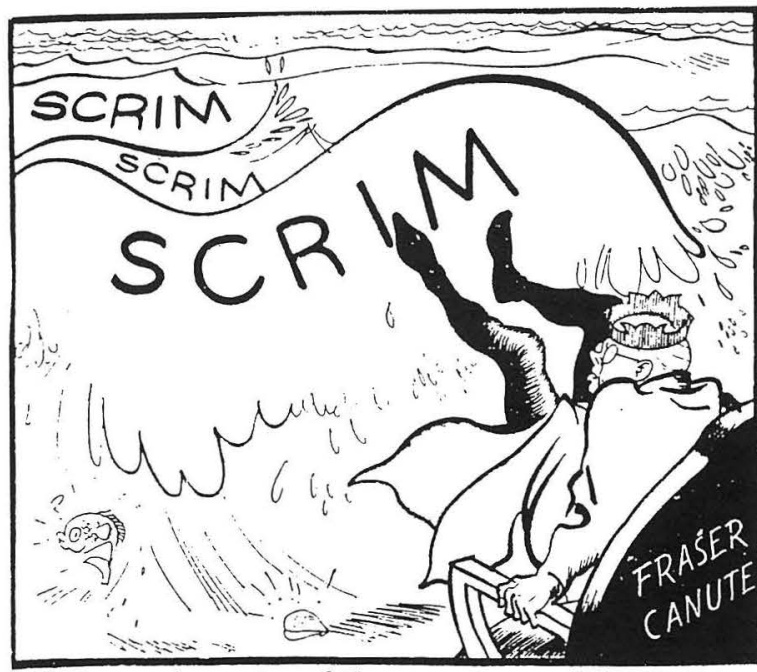

Scrimgeour's version of the agreement and the Minister described it as improper and improbable. Fraser seized the initiative and on 18 June 1943 Scrimgeour was formally dismissed as Controller. Thus ended his New Zealand radio career.

The amalgamation of the two broadcasting services was reconsidered and implemented with Shelley in overall charge. The Government investigated and assessed all the personnel of the commercial stations for their loyalty. Descriptions such as 'Most dangerous', 'Fanatical Scrim-ite, suspected of being a member of the Communist Party', 'Responsible for Scrim joining the Waterside Workers' Union' and 'Needs careful watching' were some of the comments of the less wellregarded staff. However there were no attempts to dismiss staff who were regarded as Scrimgeour loyalists.

It was not the end of Scrimgeour's public prominence in 1943. He stood as an independent candidate in the 1943 election opposing Peter Fraser for Wellington Central. It was a bitter campaign with personal and acrimonious accusations being made by both Scrimgeour and Fraser. Fraser won his seat easily enough but saw his majority drop to less than a majority of the votes cast. Returning to the Air Force after the campaign Scrimgeour was pronounced medically unfit for overseas service. He was discharged in November 1944 and he and his family left to live and work in Australia.

John A. Lee wrote in 1941: 'Scrim is a national institution. To tens of thousands he is Saint Radio and to some thousand Radio Satan'. He was neither of these extremes but was a fascinating combination of altruism and veniality that combined with a broadcasting brilliance to make him a national character of compelling interest and importance. Negatively, the ghost of Scrimgeour haunted the broadcasting studios and, particularly, the nightmares of successive Above: An optimistic view of Scrimgeour's 1943 election prospects.
Ministers of Broadcasting, at least until the founding of the New Zealand Broadcasting Corporation in 1961. It was the memory of Scrimgeour that, more than any other influence, kept free and open discussion out of the broadcasting media until the 1960s. The New Zealand usage of radio was decided politically and, for that reason, Scrimgeour is not the pivotal figure in early radio. That distinction, if distinction it is, rests with Michael Joseph Savage. Savage did not win all his battles in broadcasting but it was he who had the political imagination, will and power to forge radio as an arm of Government, an action that was continued by his successor Governments until the 1960s. But Scrimgeour was the unquestioned major broadcaster of his era, the only figure to evade and then rise above the general prohibition on free speech over the airwaves. Before and after the 1935 Labour victory he maintained a huge and loyal audience. As Controller of Commercial Broadcasting he was the architect and builder who gave expression to Savage's decision to develop radio as a form of commercial, popular entertainment. Scrimgeour's rival, Shelley, outlasted him and developed a New Zealand version of Reithian broadcasting. But the majority New Zealand audience was always determinedly low-brow and Colin Scrimgeour was the man who developed the populist form of entertainment, run by a commercial Government Department and supporting the ruling political Party, that was distinctive of New Zealand radio until the 1960s.

\section{References}

Auckland Star

Broadcasting Archives, National Archives

Clarkson T.R. 'Reminiscences of Radio', 1981, Telecom Museum and Archives

'Coming of Age.The Friendly Road 21 Today. 1929-1950', Alexander Turnbull Library

Les Edwards, Scrim: Radio Rebel in Retrospect, Hodder \& Stoughton Auckland, 1971

Katipo

John A. Lee's Weekly

Mackay Papers, Alexander Turnbull Library

Nash Papers, National Archives

New Zealand Herald

New Zealand Listener

New Zealand Observer

New Zealand Parliamentary Debates

Radio New Zealand Sound Archives

Radio Record

Scrimgeour Papers. Alexander Turnbull Library

C.G. Scrimgeour, JohnA. Lee, Tony Simpson, The Scrim-Lee Papers, Reed, Wellington, 1976

Tony Simpson, The Sugarbag Years. Taylor, Wellington, 1974

This paper was presented at a Stout Centre Seminar on 18 September 1991. Patrick Day has been commissioned to write a history of broadcasting in New Zealand. 